\title{
Perancangan Sistem Pendaftaran Audiens Seminar Proposal di Institut Agama Islam Negeri (IAIN) Bukittinggi
}

\author{
M R Darmawan ${ }^{1}$, H A Musril ${ }^{2}$ \\ Program Studi Pendidikan Teknik Informatika dan Komputer, Institut Agama Islam Negeri \\ Bukittinggi ${ }^{12}$ \\ Jl. Gurun Aur Kubang Putih, Aur Birugo Tigo Baleh, Bukittinggi, 26181, Indonesia ${ }^{12}$ \\ mrisqid@gmail.com*1, hari.antonimusrril@iainbukittinggi.ac.id ${ }^{2}$
}

diterima: 21 Juli 2020

direvisi: 29 Oktober 2020

dipublikasi: 1 Maret 2021

\begin{abstract}
Abstrak
Permasalahan pelaksanaan seminar proposal di Institut Agama Islam Negeri Bukittinggi masih belum efektif dan efesien karena dalam pengolahan data pelaksanaan seminar proposal masih dilakukan secara manual sehingga mengakibatkan terjadinya audiens yang menghadiri seminar proposal berpeluang untuk melakukan kecurangan, jumlah audiens yang berlebihan, dan menghambat proses pemeriksaan keaslian kartu tanda menghadiri seminar proposal oleh mahasiswa yang hadir sebagai audiens. Dengan adanya permasalahan tersebut, penulis bertujuan untuk merancang suatu sistem pendaftaran audiens seminar proposal yang dapat membantu mahasiswa dalam mencari jadwal seminar proposal, memilih jadwal seminar proposal yang akan diikuti, mencetak kartu tanda menghadiri seminar proposal, serta membantu ketua program studi dalam mengelola data jadwal dan mencetak absensi audiens. Jenis Penelitian yang digunakan adalah Research and Development (R\&D) dimana urutan-urutan kegiatan yang dilakukan secara sistematis sehingga memudahkan dalam perancangan sistem pendaftaran audiens seminar proposal. Dengan adanya sistem pendaftaran audiens seminar proposal maka memudahkan dalam pengelolaan jadwal seminar proposal, memudahkan akses dimana saja dengan internet, dan pelaksanaan seminar proposal menjadi lebih efektif dan efesien karena sistem yang digunakan berbasis database dan online.
\end{abstract}

Kata kunci: Seminar Proposal; Audiens Seminar Proposal; Sistem Pendaftaran Audiens Seminar Proposal

\begin{abstract}
Problems with the implementation of the proposal seminar contained in Institut Agama Islam Negeri Bukittinggi are still not effective and efficient because in processing the proposal seminar implementation data is still done manually resulting in an audience attending the proposal seminar has the opportunity to commit fraud, excessive audience numbers, and hinder the process of checking the authenticity of sign cards attending proposal seminars by students present as audiences. With these problems, the author aims to design a seminar audience registration system that can assist students in finding a proposal seminar schedule, choosing a proposal seminar schedule to be followed, printing a signed card to attend the proposal seminar, and assisting the head of the study program in managing schedule data and print audience absences. The type of research used is Research and Development $(R \& D$ in which the sequence of activities carried out systematically makes it easier to design a seminar audience registration system. With the seminar audience registration system, it makes it easy to manage the proposal seminar schedule, makes it easy to access anywhere with internet, and the implementation of proposal seminars becomes more effective and efficient because the system used is based on databases and online.
\end{abstract}

Keywords: Proposal Seminar; Proposal Seminar Audiences; Seminar Audiences Registration System 


\section{Pendahuluan}

Perguruan Tinggi adalah lembaga formal tertinggi tempat masyarakat menimba pendidikan. Lembaga ini menerapkan program pendidikan dengan melibatkan berbagai komponen yang terdapat di dalamnya. Salah satu komponen yang terpenting dalam sebuah lembaga perguruan tinggi adalah mahasiswa. Berhasil atau tidaknya suatu lembaga ini dapat dilihat dari kuantitas dan kualitas mahasiswa yang menjadi ujung tombak dari perguruan tinggi tersebut [1]. Salah satu lembaga perguruan tinggi tersebut ialah Institut Agama Islam Negeri (IAIN) Bukittinggi.

IAIN Bukittinggi merupakan salah satu Perguruan Tinggi Negeri Islam yang sedang berkembang di Kota Bukittinggi dimana saat ini telah memiliki ribuan orang mahasiswa dan berkembang pesat dari tahun ke tahun. Terdiri dari beberapa Fakultas, salah satunya Fakultas Tarbiyah dan Ilmu Keguruan (FTIK), salah satu program studi (prodi) di FTIK adalah prodi Pendidikan Teknik Informatika dan Komputer (PTIK). Bagian Prodi adalah suatu bagian yang memiliki sarana penting untuk mendapatkan informasi yang berguna bagi mahasiswa dalam proses perkuliahan, salah satunya dalam mempersiapkan tugas akhir (skripsi) [2].

Skripsi adalah istilah yang digunakan di Indonesia untuk mengilustrasikan suatu karya tulis ilmiah berupa paparan tulisan hasil penelitian sarjana S1 yang membahas suatu permasalahan atau fenomena dalam bidang ilmu tertentu dengan menggunakan kaidahkaidah yang berlaku [2]. IAIN Bukittinggi mewajibkan mahasiswa menulis skripsi sebagai persyaratan untuk memperoleh gelar sarjana. Masalah dan metode penelitian yang dipilih sebagai kajian skripsi akan ditentukan mahasiswa sesuai dengan minat tetapi ruang lingkup kajian harus sesuai dengan program studi (prodi).

Salah satu syarat untuk menyelesaikan tugas akhir ini adalah dengan menghadiri seminar proposal sebagai audiens, sebelum mahasiswa yang bersangkutan mendaftar sebagai presenter seminar proposal. Seminar proposal adalah tahapan setelah proposal yang disusun oleh mahasiswa telah selesai dan dinyatakan layak oleh dosen pembimbing untuk diseminarkan. Biasanya bentuk pernyataan layak adalah dengan ditandatangani pada lembar persetujuan proposal penelitian [3].

Sebelum melakukan seminar proposal ini ada beberapa hal yang harus disiapkan oleh mahasiswa, salah satunya adalah kartu bukti tanda pernah menghadiri seminar proposal (sebagai audiens) yang sebelumnya telah dilakukan pada prodi masing-masing. Dalam kebijakan yang diatur pada buku pedoman akademik Institut Agama Islam Negeri (IAIN) Bukittinggi bahwa seminar proposal akan dilaksanakan dengan ketentuan yang harus dipenuhi salah satunya yaitu mahasiswa yang akan seminar telah mengikuti seminar proposal minimal 10 kali [4].

Pada saat seminar proposal diadakan, para mahasiswa atau audiens yang menghadiri acara seminar proposal tersebut membawa selembar kertas sebagai bukti kartu telah mengikuti seminar dimana pada saat seminar telah selesai kartu tersebut dikumpulkan dan ditanda tangani oleh sekretaris seminar proposal. Sebelum mengumpulkan kartu tanda pernah menghadiri seminar proposal mahasiswa atau audiens yang bersangkutan harus mengisi hari dan tanggal seminar, nama mahasiswa yang seminar, judul proposal mahasiswa yang seminar terlebih dahulu pada kartu tanda pernah menghadiri seminar proposal masing-masing.

Pada saat ini pelaksanaan seminar proposal masih belum praktis, efektif dan efesien, dikarenakan masih terdapat beberapa kendala seperti pengelolaan data yang masih manual, dan belum adanya web sistem pendaftaran dan sistem informasi jadwal seminar proposal. Maka dari itu penulis memberikan solusi bahwa perlu adanya sistem yang terkomputerisasi 
yang dapat mengatur dan membantu kerja dari beberapa pihak seperti mahasiswa dan ketua program studi.

Salah satu sistem yang dapat membantu proses tersebut adalah sistem pendaftaran audiens seminar proposal. Sistem ini berupa web yang menggunakan bahasa pemograman $P H P$ dan database MySQL, serta berbasis online internet supaya bisa diakses dari mana saja. Dengan adanya sebuah sistem yang digunakan sebagai bukti tanda menghadiri seminar proposal, maka mahasiswa yang akan mengikuti seminar proposal tersebut adalah benar-benar telah memenuhi syarat-syarat untuk seminar proposal, salah satunya adalah dengan melengkapi tandatangan pada kartu tanda pernah menghadiri seminar proposal.

\subsection{Perancangan}

\section{Kajian Pustaka}

Perancangan merupakan tahap analisa dalam kaitan mencari atau merumuskan alternatif-alternatif pemecahan masalah [5]. Menurut Jogiyanto perancangan mempunyai dua maksud, yaitu untuk memenuhi kebutuhan kepada pemakai sistem dan untuk memberikan gambaran yang jelas kepada pemogram komputer dan ahli-ahli teknik lainnya yang terlibat [6].

\subsection{Sistem}

Sistem berasal dari bahasa latin (system) dan bahasa Yunani (sustema) adalah suatu yang terdiri dari komponen atau elemen yang dihubungkan bersama untuk memudahkan aliran sistem informasi, materi atau energy [7].

\subsection{Pendaftaran}

Menurut Depdikbud pengertian pendaftaran adalah proses, cara, perbuatan mendaftar yaitu pencatatan nama, alamat dan sebagainya dalam daftar. Jadi, pendaftaran adalah proses pencatatan identitas pendaftar kedalam sebuah media penyimpanan yang digunakan dalam proses pendaftaran [8].

\subsection{Audiens}

Secara sederhana, kata khalayak atau audiensi yang diterjemahkan dari kata "audience" secara sejarah berasal dari kata audire yang berarti mendengar dalam bahasa Yunani. Dalam Kamus Besar Bahasa Indonesia, khalayak diartikan salah satunya sebagai "Kelompok tertentu dalam masyarakat yang menjadi sasaran komunikasi" [9]. Jadi audiens adalah Kunjungan kehormatan, pengunjung atau pendengar suatu ceramah dan sebagainya.

\subsection{Seminar Proposal}

Seminar proposal adalah tahapan setelah proposal yang disusun oleh Mahasiswa telah selesai dan dinyatakan layak oleh dosen pembimbing untuk diseminarkan. Biasanya bentuk pernyataan layak adalah dengan ditanda tangani pada lembar persetujuan proposal penelitian. Seminar proposal akan dijuji oleh beberapa dosen penguji, terdiri dari satu orang pembimbing dan dua orang penguji [3].

\subsection{PHP}

PHP merupakan singkatan dari Hypertext Preprocessor. Adalah bahasa berbentuk skrip yang ditempatkan dalam server dan diproses di server. Secara khusus, PHP dirancang untuk membentuk aplikasi web dinamis. Artinya, ia dapat membentuk suatu tampilan berdasarkan permintaan terkini [10]. 


\subsection{MySQL}

MySQL adalah salah satu program yang dapat digunakan sebagai database, dan merupakan salah satu software untuk database server yang banyak digunakan. MySQL bersifat open source dan menggunakan $S Q L$. MySQL bisa dijalankan diberbagai platform misalnya Windows, Linux, dan sebagainya [11].

\subsection{Unified Modelling Language (UML)}

Pada perkembangan teknik pemrograman berorientasi objek, muncullah sebuah standarisasi bahasa pemodelan untuk pembangunan perangkat lunak yang dibangun dengan menggunakan teknik pemrograman berorientasi objek, yaitu Unified Modeling Language (UML). UML adalah sebuah bahasa yang berdasarkan grafik atau gambar untuk memvisualisasikan, menspesifikasikan, membangun, dan pendokumentasian dari sebuah sistem pengembangan software berbasis OO (Object-Oriented) [12].

UML terdiri dari beberapa macam diantaranya yaitu [13]:

a. Use case diagram

Use case atau diagram use case adalah pemodelan untuk kelakuan (behavior) sistem informasi yang akan dibuat. Use case mendiskripsikan sebuah interaksi antara satu atau lebih aktor dengan sistem informasi yang akan dibuat.

b. Activity diagram

Diagram aktivitas atau activity diagram menggambarkan workflow (aliran kerja) atau aktivitas dari sebuah sistem atau menu yang ada pada perangkat lunak. Yang perlu diperhatikan adalah bahwa diagram aktivitas menggambarkan aktivitas sistem bukan apa yang dilakukan aktor, jadi aktivitas yang dapat dilakukan oleh sistem.

c. Sequence diagram

Diagram sequence menggambarkan kelakuan objek pada use case dengan mendiskripsikan waktu hidup objek dan message yang dikirimkan dan diterima antar objek. Oleh karena itu untuk menggambarkan diagram sequence maka harus diketahui objek-objek yang terlibat dalam sebuah use case beserta metode-metode yang dimiliki kelas yang diinstansiasi menjadi objek itu.

d. Class diagram

Diagram kelas atau class diagram menggambarkan struktur sistem dari segi pendefenisian kelas-kelas yang akan dibuat untuk membangaun sistem kelas memiliki apa yang disebut atribut dan metode atau operasi.

\subsection{Flowchart}

Flowchart adalah bagan-bagan yang mempunyai arus yang menggambarkan langkahlangkah penyelesaian suatu masalah. Jadi flowchart merupakan cara penyajian dari suatu algoritma [14].

\subsection{Metode $R \& D$}

\section{Metode Penelitian}

Jenis Penelitian yang digunakan adalah Penelitian dan Pengembangan (Research and Development). Research and Development $(\mathrm{R} \& \mathrm{D})$ adalah proses yang dimaksudkan untuk menciptakan teknologi baru atau meningkatkan sesuatu yang dapat memberikan keunggulan kompetitif di industri, bisnis, atau tingkat nasional [15]. Dalam penelitian ini penulis menggunakan model pengembangan $\mathrm{R} \& \mathrm{D}$ adalah versi 4-D (Four D) dikembangkan oleh Thiagarajan Tahun 1974. Four-D model ini terdiri dari pendefinisian 
(define), tahap perancangan (design), tahap pengembangan (develop), dan tahap uji coba (disseminate) [16].

Kegiatan-kegiatan yang dilakukan pada setiap tahap pengembangan dapat terlihat pada gambar sebagai berikut [15] :

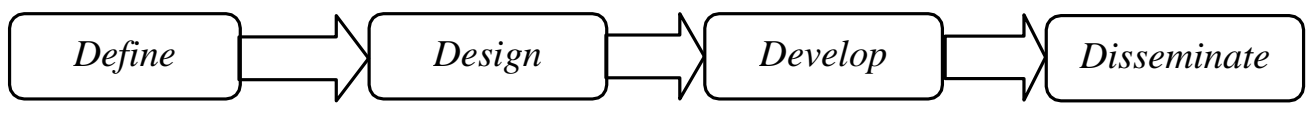

Gambar 1. Pengembangan Model 4D

\subsection{Siklus SDLC (System Development Life Cycle)}

Software Development Life Cycle atau sering disebut juga System Development Life Cycle (SDLC) adalah proses mengembangkan atau mengubah suatu sistem perangkat lunak dengan menggunakan model-model dan metodologi yang digunakan orang untuk mengembangkan sisitem-sistem perangkat lunak sebelumnya.

SDLC memiliki beberapa model dalam penerapan tahapan prosesnya. Dari beberpa model yang ada penulis menerapkan model waterfall. Menurut Pressman, model waterfall adalah model klasik yang bersifat sistematis, berurutan dalam membangun software. Nama model ini sebenarnya adalah "Linear Sequential Model". Dan model ini sering disebut juga dengan "classic life cycle" atau metode waterfall.

Fase-fase dalam Waterfall Model menurut Pressman sebagai berikut [17] :

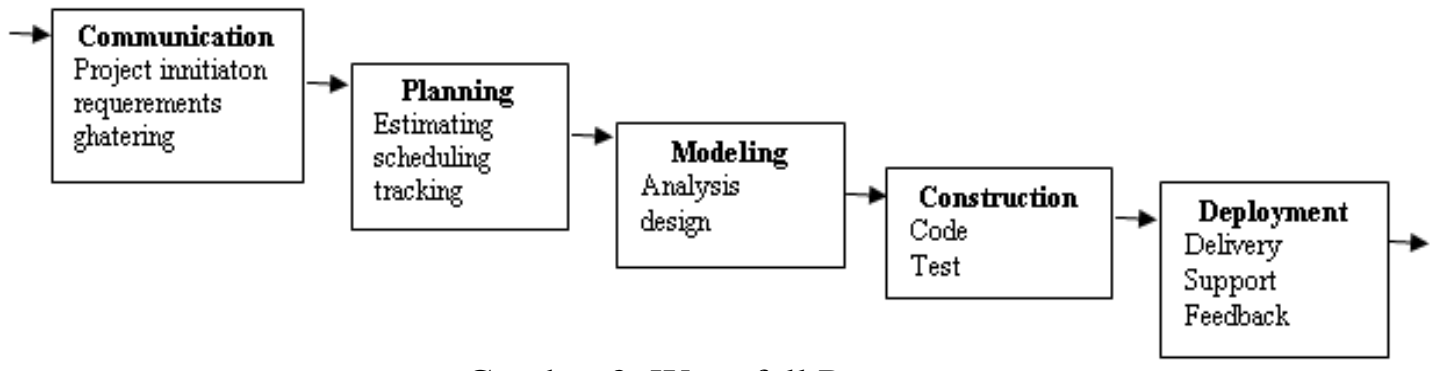

Gambar 2. Waterfall Pressman

\subsection{Tahapan Penelitian}

Tahapan penelitian yang penulis laksanakan yaitu mengkolaborasikan metode R\&D versi 4-D dan model pengembangan sistem dari Waterfall. Tahapan penelitian yang dilakukan dapat dilihat pada gambaran di bawah ini : 


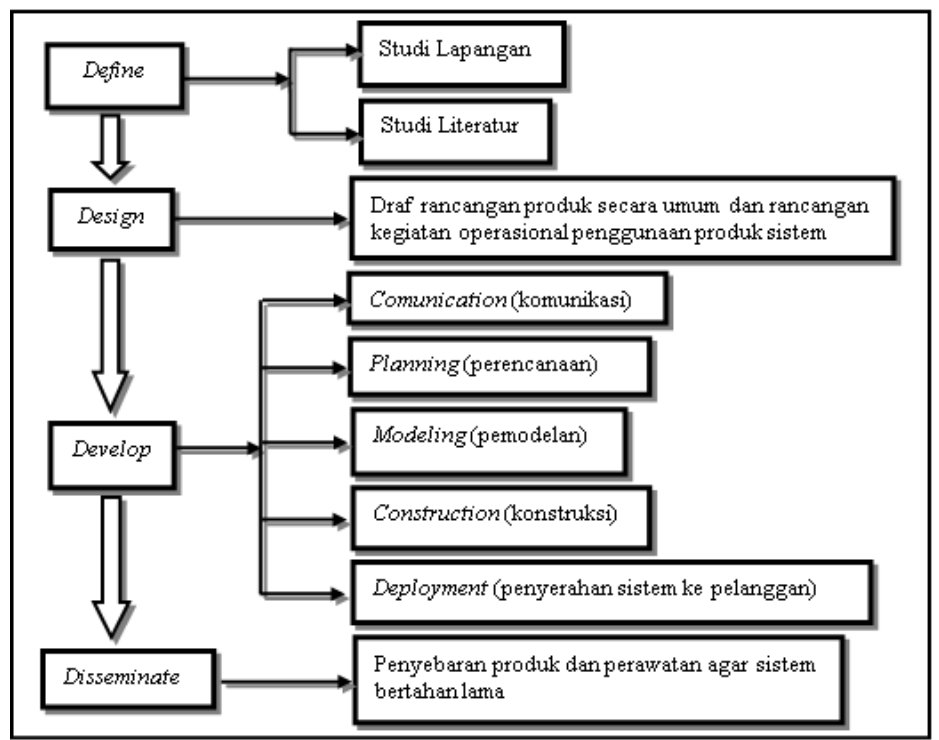

Gambar 3. Skema Tahapan Penelitian

\subsection{Rumus Uji Produk}

a. Uji Validitas Produk

Uji validitas diolah dengan mengacu rumus statistik Aiken's V sebagai berikut [18]:

$$
\mathrm{V}=\sum \mathrm{s} /[\mathrm{n}(\mathrm{c}-1)]
$$

Keterangan :

$$
\begin{array}{ll}
\mathrm{s} & : \mathrm{r}-\mathrm{lo} \\
\mathrm{lo} & : \text { Angka penilaian validitas yang terendah } \\
\mathrm{c} & : \text { Angka penilaian validitas yang tertinggi } \\
\mathrm{r} & : \text { Angka yang diberikan oleh seorang penilai } \\
\mathrm{n} & \text { : Jumlah penilai }
\end{array}
$$

Tabel 1. Kriteria Penentuan Validitas Aiken's V

\begin{tabular}{|c|c|}
\hline Persentase \% & Kriteria \\
\hline $0,6<$ & Tidak Valid \\
\hline$>=0,6$ & Valid \\
\hline
\end{tabular}

b. Uji Praktikalitas Produk

Uji praktikalitas diolah menggunakan rumus moment kappa, sebagai berikut [19]:

$$
K=\frac{\rho-\rho e}{1-\rho e}
$$

Keterangan :

$\mathrm{K} \quad$ : Moment kappa yang menunjukkan kepraktisan produk

$\rho \quad$ : Proporsi yang terealisasi, dihitung dengan cara jumlah nilai yang diberikan oleh penguji dibagi jumlah maksimal

$\rho e \quad$ : Proporsi yang tidak terealisasi, dihitung dengan cara jumlah nilai maksimal dikurangi dengan jumlah total yang diberikan oleh penguji dibagi jumlah maksimal 
Tabel 2. Kriteria Penentuan Praktikalitas Moment Kappa

\begin{tabular}{|c|c|}
\hline Interval & Kategori \\
\hline $0,81-1,00$ & Sangat tinggi \\
\hline $0,61-0,80$ & Tinggi \\
\hline $0,41-0,60$ & Sedang \\
\hline $0,21-0,40$ & Rendah \\
\hline $0,01-0,20$ & Sangat Rendah \\
\hline$\leq 0,00$ & Tidak praktis \\
\hline
\end{tabular}

c. Uji Efektifitas Produk

Uji efektifitas diolah dengan mengacu rumus statistik Richard R. Hake (G-Score) sebagai berikut [20] :

$$
<g>=\frac{(\%<S f>-\%<S i>)}{(100-\%<S i>)}
$$

Keterangan :

$$
\begin{array}{ll}
<\mathrm{g}> & : G \text {-Score } \\
<\mathrm{Sf}> & : \text { Score } \text { akhir } \\
<\mathrm{Si}> & : \text { Score awal }
\end{array}
$$

Kriteria setiap indikator dari lembar uji sebagai berikut [20] :

"High-g" efektifitas tinggi jika mempunyai $(<\mathrm{g}>)>0.7$.

"Medium-g" efektifitas sedang jika mempunyai $0.7>(<\mathrm{g}>)>0.3$.

"Low-g" efektifitas rendah jika mempunyai $(<\mathrm{g}>)<0.3$.

\subsection{Hasil}

\section{Hasil dan Pembahasan}

Hasil penelitian yang didapatkan dari perancangan sistem pendaftaran audiens seminar proposal di IAIN Bukittinggi menghasilkan sebuah sistem dalam bentuk website yang difungsikan pengguna untuk membantu kampus dalam melakukan pendaftaran audiens seminar proposal di IAIN Bukittinggi. Penelitian ini menghasilkan sebuah web dengan url https://mrd-sipaspro.epizy.com yang akan difungsikan pengguna untuk membantu kampus dalam pengolahan serta mngetahui informasi pendaftaran audiens seminar proposal di prodi Pendidikan Teknik Informatika dan Komputer (PTIK).

Penulis telah melakukan uji program tersebut kepada para ahli dibidang komputer maupun ahli dibidang pendidikan beserta beberapa mahasiswa. Hasil yang peneliti dapatkan yaitu sistem yang penulis buat adalah valid dengan nilai 0,93, tingkat praktikalitas tinggi dengan nilai 0,697 , dan tingkat efektifitas tinggi dengan nilai 0,872 untuk digunakan di prodi Pendidikan Teknik Informatika dan Komputer (PTIK) IAIN Bukittinggi.

\subsection{Pembahasan}

\subsubsection{Define}

Pendefenisian ini merupakan mencari informasi data dari tempat penelitian yang digunakan, sehingga memudahkan penulis dalam menerjemahkan masalah yang timbul. Sebagaimana yang telah dijelaskan dilatar belakang masalah. Manfaat dari sistem pendaftaran seminar proposal ini sebagai alat bantu untuk memudahkan 
pihak yang bersangkutan dalam mengetahui dan memperoleh informasi sejauh mana perkembangan dalam proses pendaftaran dan menghadiri seminar proposal di IAIN Bukittinggi.

\subsubsection{Design}

Dalam tahap desain ini penulis merancang sebuah sistem berdasarkan kebutuhan dari kampus untuk memudahkan Prodi dalam pengelolaan dan memproses pendaftaran audiens semianar proposal yang sudah didaftarakan oleh audiens. Berikut alur desain akses user ke sistem sebagai berikut :

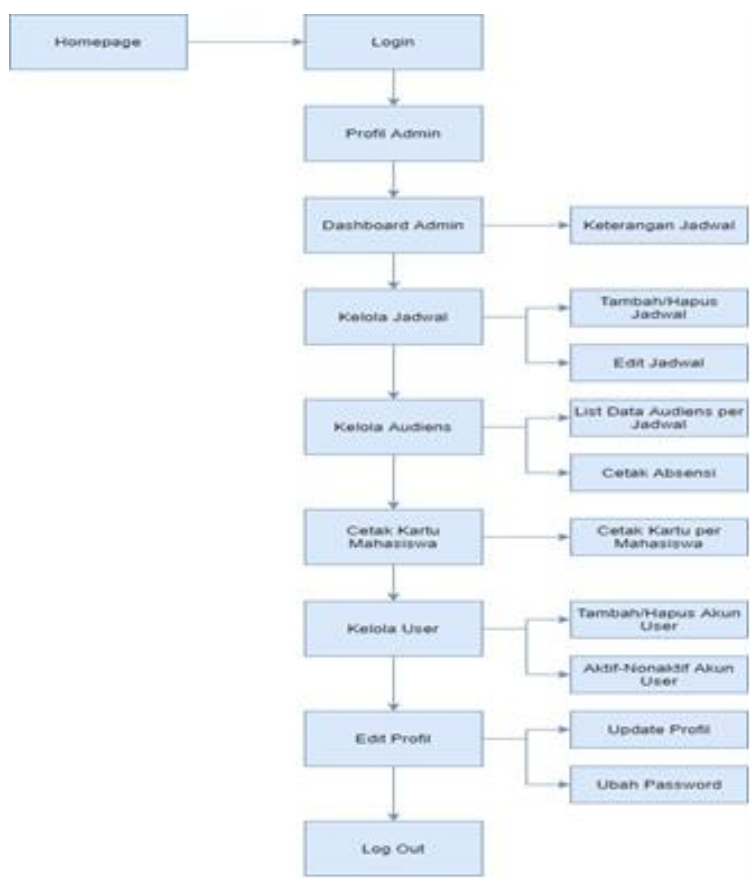

Gambar 4. Desain Sistem Admin

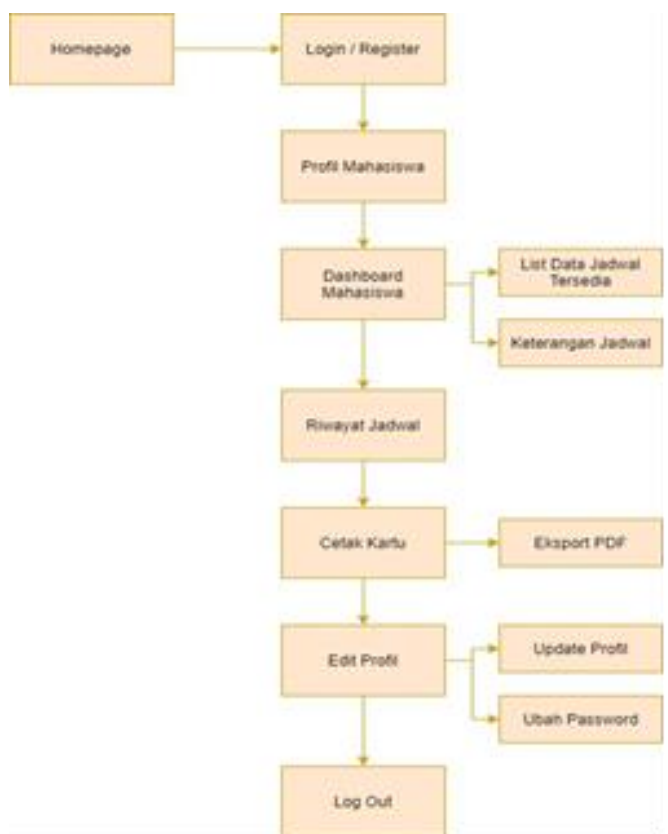

Gambar 5. Desain Sistem User/Mahasiswa

\subsubsection{Develop}




\subsubsection{Communication (Project Innitiation, Requirement Ghatering)}

a. Project Innitiation (Inisiasi Proyek)

Pada tahap ini, peneliti melakukan kegiatan wawancara dengan Bapak Riri Okra M. Kom sebagai Ketua Prodi Pendidikan Tenknik Informatika dan Komputer (PTIK) IAIN Bukittinggi, beliau menyampaiakan bahwa salah satu persyaratan mahasiswa untuk mengikuti seminar proposal yaitu menyerahkan kartu tanda pernah menghadiri seminar proposal minimal delapan kali dan sudah ditandatangani ketua seminar proposal yang pernah diikuti. Namun ada beberapa masalah dan kendala-kendala yang dihadapi oleh bapak Riri Okra M. Kom selama menjabat sebagai ketua prodi PTIK terkait seminar proposal yaitu: pertama, mengenai sistem kartu tanda menghadiri seminar proposal tersebut, pada saat ini masih manual, yaitu ketika seminar proposal berlangsung kartu tanda menghadiri seminar proposal yang sudah diisi akan dikumpulkan kepada sekretaris seminar proposal untuk dicek dan ditandatangani oleh ketua seminar proposal. Namun, pada saat kartu tanda menghadiri seminar proposal dicek jumlah kartu tersebut lebih banyak daripada mahasiswa yang hadir sebagai audiens.

b. Requirement Gathering (Pengumpulan Kebutuhan)

Tahap ini menentukan kebutuhan user, kebutuhan sistem, kebutuhan SDM, dan kebutuhan teknologi

4.2.3.2 Planning (Estimating, Scedhulling, Tracking)

a. Estimating (Perkiraan Tugas)

Tahapan ini mendefinisikan tugas yang dapat dilakukan mahasiswa, dan admin.

b. Schedulling (Penjadwalan)

Pembuatan sistem ini dalam rentang waktu bulan mei dari tanggal 1 sampai 30 Mei 2020.

c. Tracking

Pada proses pengerjaan sistemnya, tahapan yang dilalui penulis adalah pertama membuat sistemnya dengan menggunakan framework back end Codeigniter 3 dan framework CSS (front end) Bootstrap 4, lalu dihostingkan supaya sistem menjadi online melalui situs infinityfree.net yang menyediakan hosting gratis, sehingga didapatkan alamat url dari sistem penulis yaitu mrd.sipaspro.epizy.com.

\subsubsection{Modelling (Struktur Data, Design)}

a. Struktur Data

Struktur data pada pembuatan dan pengisian pendaftaran seminar proposal di sistem, pada saat perancangan sistem penulis menggunakan framework back end Codeigniter 3 dan framework css (front end) Bootstrap 4.

b. Design

1) Use Case Diagram 
Volume 11 Nomor 1 Edisi Maret 2021

P-ISSN 2088-2270, E-ISSN 2655-6839

DOI 10.34010/jati.v11i1

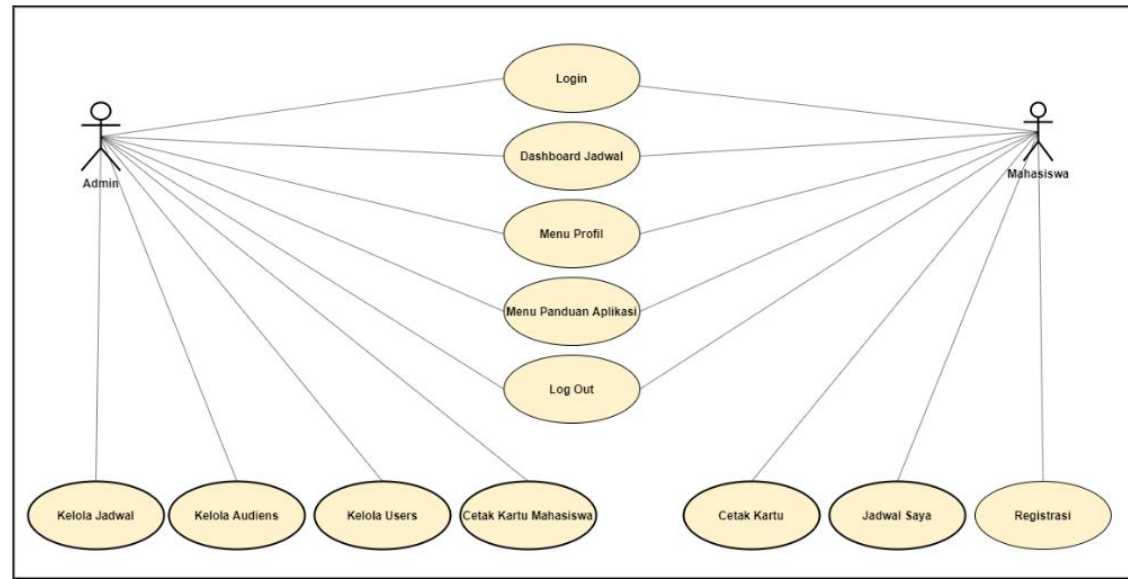

Gambar 6. Use case diagram sistem

2) Activity Diagram Admin

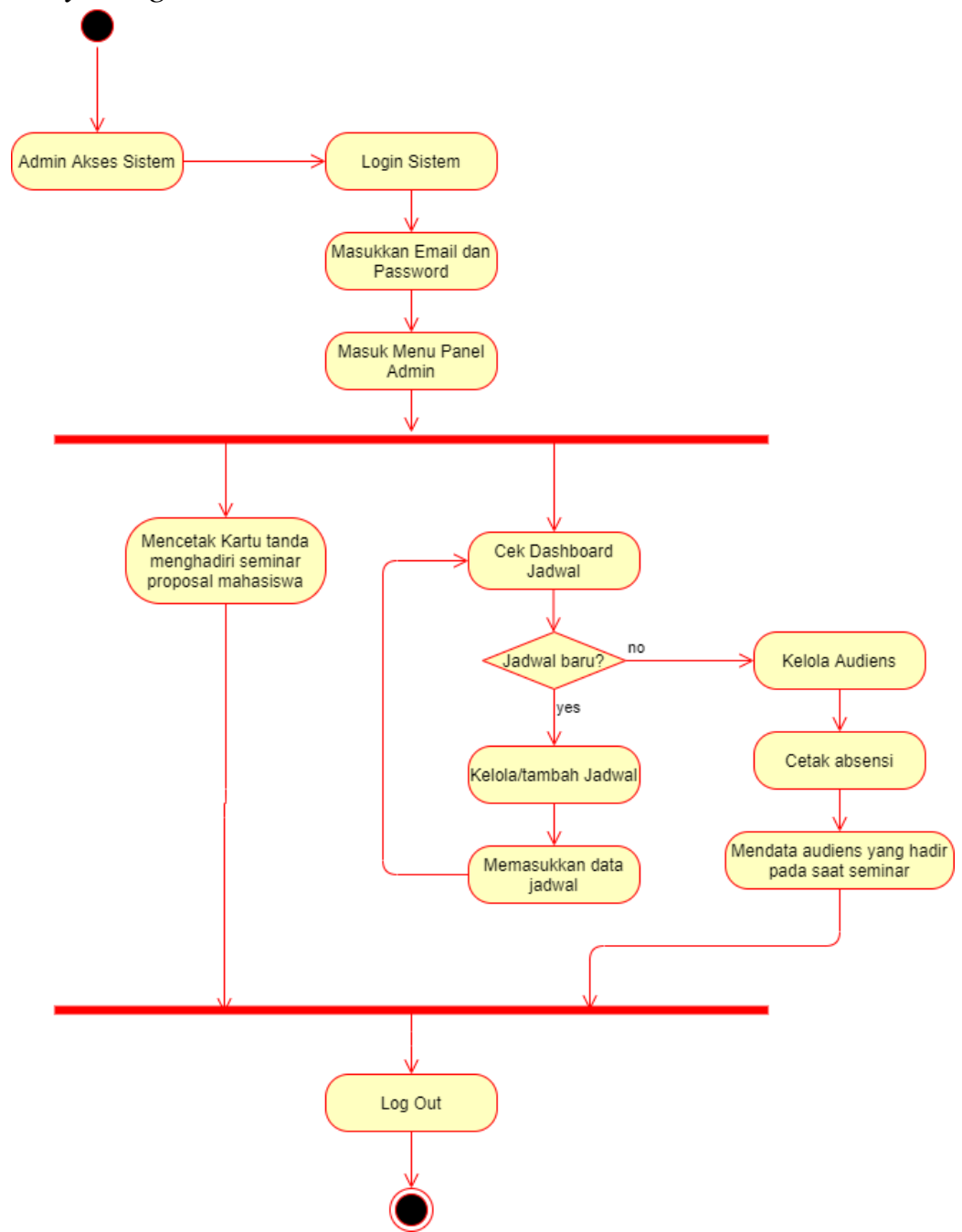

Gambar 7. Activity diagram admin

3) Activity Diagram Mahasiswa/user 
Volume 11 Nomor 1 Edisi Maret 2021

P-ISSN 2088-2270, E-ISSN 2655-6839

DOI 10.34010/jati.v11i1

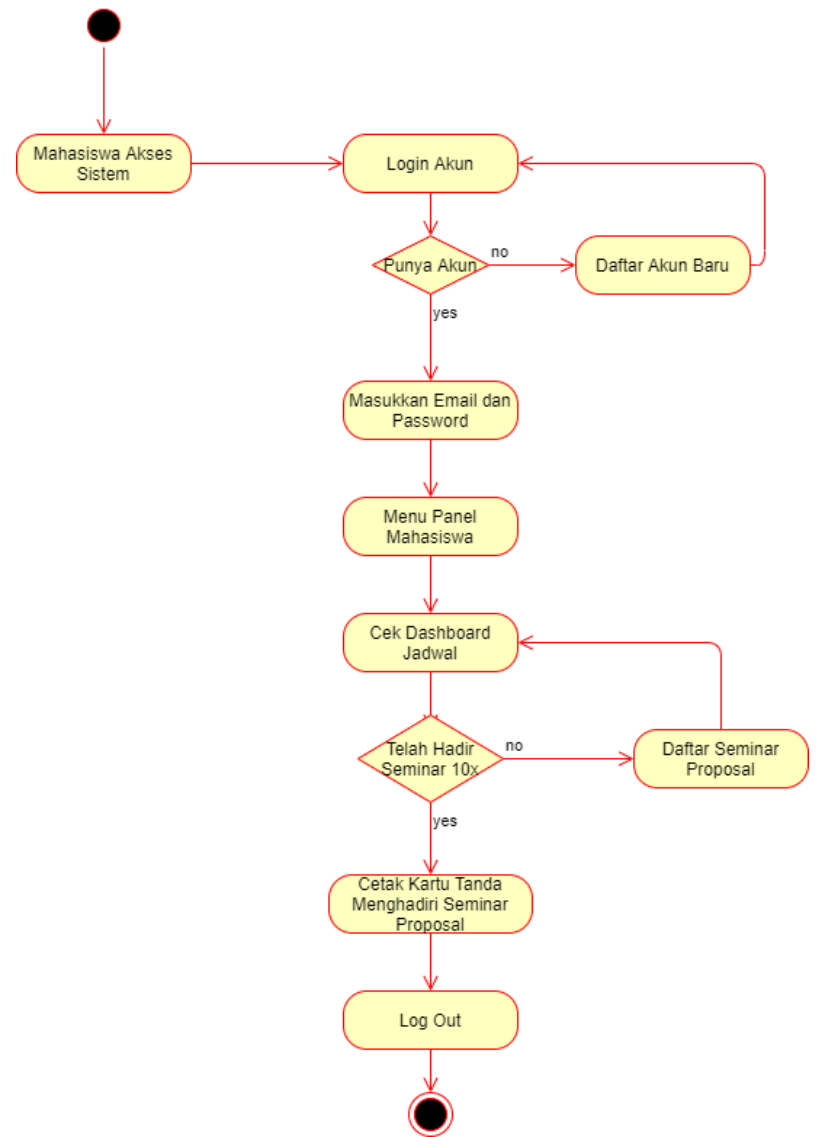

Gambar 8. Activity diagram mahasiswa

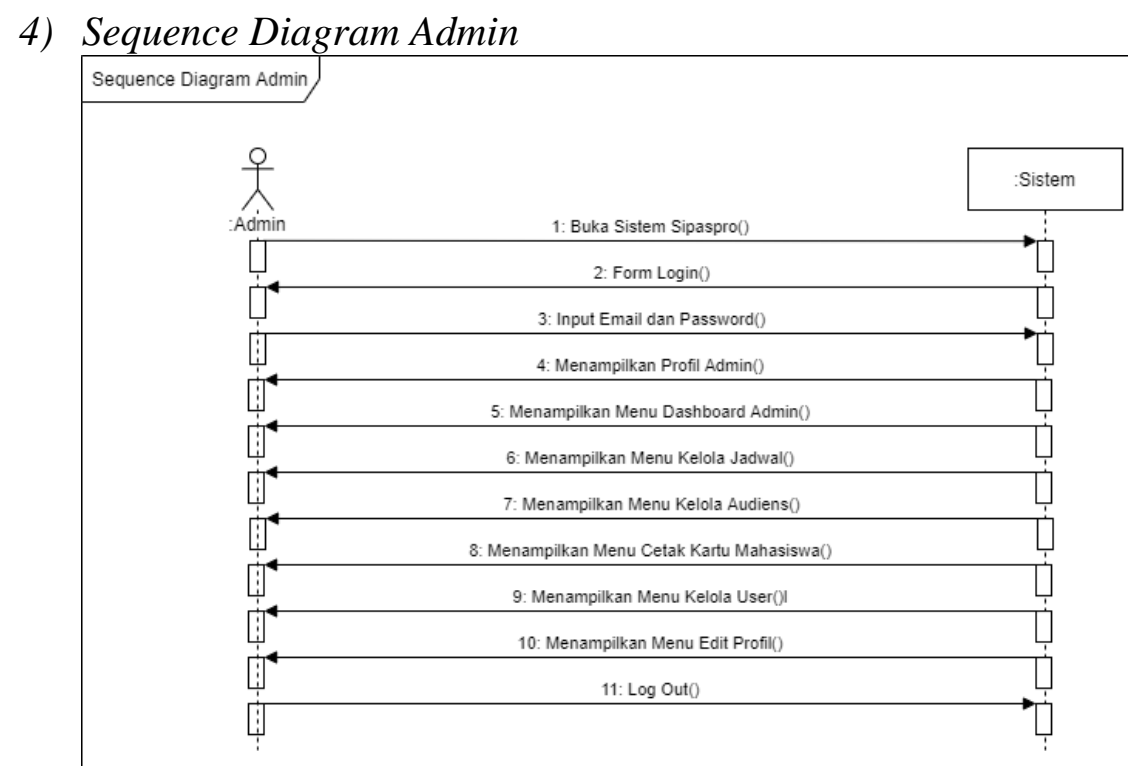

Gambar 9. Sequence diagram admin 
5) Sequence Diagram Mahasiswa/user

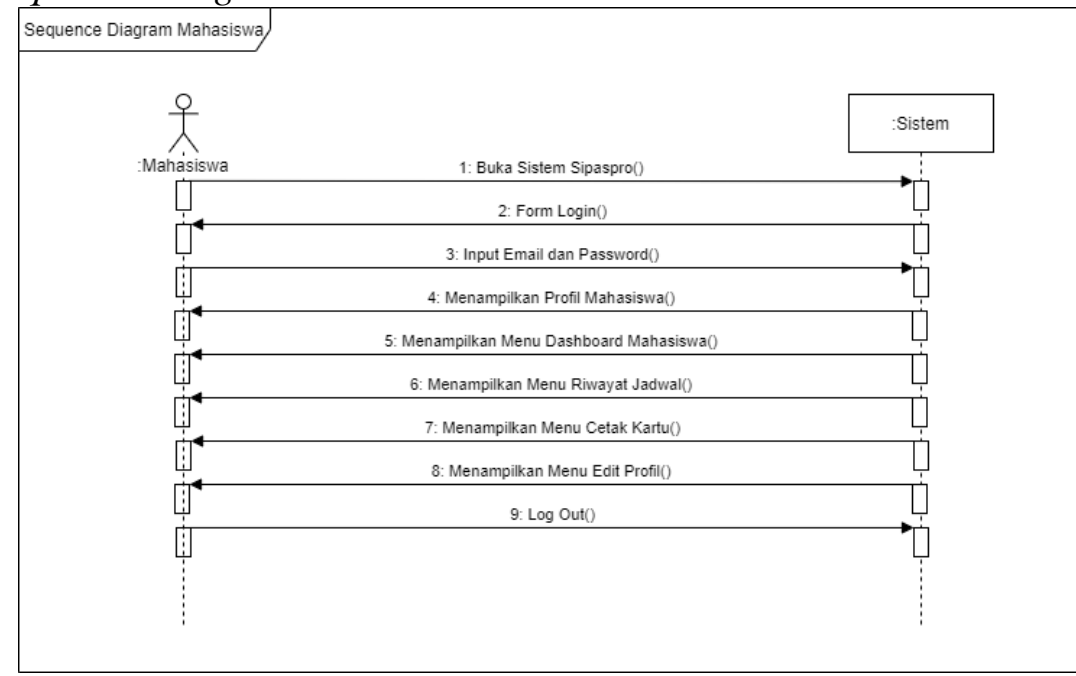

Gambar 10. Sequence diagram mahasiswa

6) Class Diagram

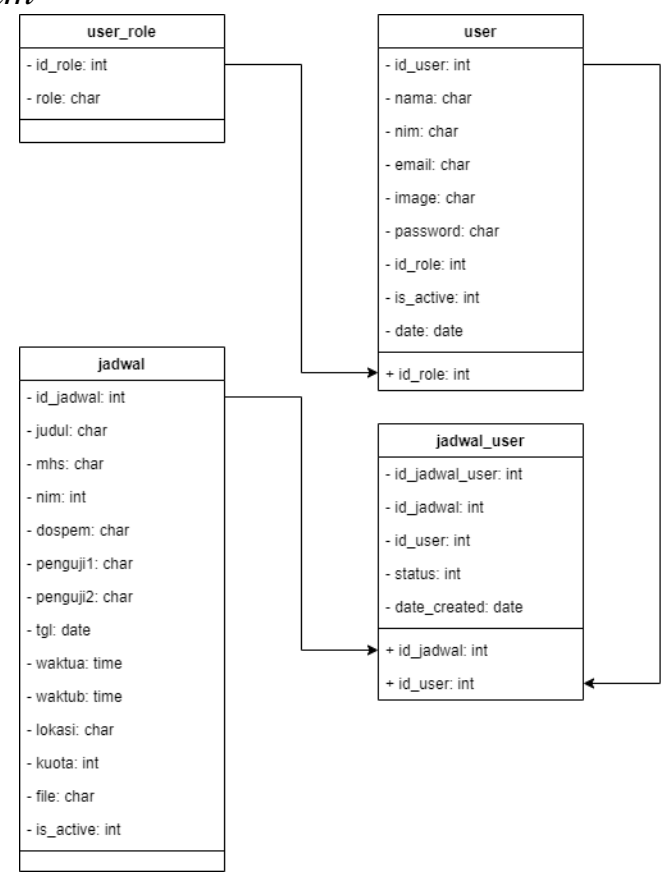

Gambar 11. Class diagram sistem

\subsubsection{Construction}

a. Coding (Sintak Program)

Sintak program yang penulis masukkan dalam aplikasi ini adalah pada form registrasi/daftar akun, login, tombol log out, form dashboard admin dan user, profil, menu Kelola jadwal, menu Kelola audiens, menu Kelola user, menu cetak kartu.

b. Testing

Penulis menggunakan black box testing untuk pengujian sistem, dimana black box testing menguji fungsi sistem tanpa melihat koding sistem.

\subsubsection{Deployment}


a. Delivery

Pengiriman produk ke user menggunakan pemanfaatan media sosial yakni, group Facebook Prodi Pendidikan Teknik Informatika dan Komputer (PTIK) IAIN Bukittinggi dan group WhatsApp Mahasiswa Prodi Pendidikan Teknik Informatika dan Komputer (PTIK) IAIN Bukittinggi.

b. Support

Memiliki manfaat untuk kampus terutama Prodi Pendidikan Teknik Informatika dan Komputer (PTIK) IAIN Bukittinggi, sistem berjalan dengan baik, sistem mudah digunakan, menarik, efisien dan inspiratif. Sistem dapat digunakan dimana saja dan kapan saja.

c. Feedback

Dalam tahap ini penulis telah melakukan pembaharuan terhadap sistem dan koreksi dari berbagai kekurangan yang telah melalui tahap pengujian dan pengujian sistem.

\subsubsection{Dessiminate}

Proses diseminasi merupakan suatu tahap akhir pengembangan. Tahap diseminasi dilakukan untuk mempromosikan produk pengembangan agar diterima pengguna, baik individu, suatu kelompok, atau sistem. Tahapan diseminasi merupakan tahap penggunaan produk final yang dihasilkan berupa sebuah sistem sipaspro (Sistem Pendaftaran Audiens Seminar Proposal). Dalam penyebaran penelitian ini hanya menggunakan group facebook kampus, group whatsapp kampus di IAIN Bukittinggi yang digunakan oleh mahasiswa dan dosen serta pegawai kampus.

\subsubsection{Uji Produk}

Hasil uji produk yang penulis lakukan, uji validitas dengan rata-rata nilai 0,93 yaitu valid, uji praktikalitas dengan rata-rata nilai 0,697 yaitu tingkat praktikalitas tinggi, dan uji efektifitas dengan rata-rata nilai 0,872 yaitu tingkat efektifitas tinggi.

\section{Kesimpulan}

Berdasarkan hasil penelitian, penulis mengambil kesimpulan bahwa dengan adanya perancangan sistem pendaftaran audiens seminar proposal ini maka penulis telah berhasil membuat pendaftaran audiens seminar proposal di Institut Agama Islam Negeri (IAIN) Bukittinggi. menghasilkan sebuah sistem pendaftaran audiens seminar proposal bernama sipaspro. Dengan adanya sistem ini maka sangat membantu pihak kampus terutama Prodi Pendidikan Teknik Informatika dan Komputer (PTIK) IAIN Bukittinggi dalam pendaftaran dan penyelenggaraan seminar proposal. Selain itu juga sangat menghemat waktu baik dalam pendaftaran maupun dalam pengolahan data mahasiswa yang melakukan pendaftaran seminar proposal, sehingga hasilnya akan lebih efektif, efisien dan valid.

Sistem pendaftaran audiens seminar proposal yang di rancang mendapat nilai validasi akhir 0,93, nilai praktikalitas akhir 0,697 dan nilai efektifitas akhir 0,872, dapat disimpulkan bahwa sistem pendaftaran seminar proposal valid, tingkat praktikalitas tinggi dan tingkat efektifitas tinggi ketika di gunakan.

\section{Daftar Pustaka}

[1] Z. Sesmiarni, "Efikasi Diri Mahasiswa Di Perguruan Tinggi," Anal. J. Pendidik., vol. 11, no. 2, pp. 115-127, 2014.

[2] A. R. Mariana, A. Budiman, and N. Septiana, "Sistem Informasi Aplikasi Penilaian Sidang Skripsi Berbasis Web di STMIK Bina Sarana Global,” J. Sisfotek Glob., vol. 
3, no. 2, pp. 18-22, 2013.

[3] M. Anangkota, "Jangan Takut Menulis Skripsi.” Deepublish, Yogyakarta, 2018.

[4] Lembaga Penjaminan Mutu (LPM) IAIN Bukittinggi, "Pedoman Akademik Institut Agama Islam Negeri (IAIN) Bukittinggi." LPM IAIN Bukittinggi, Bukittinggi, 2018.

[5] D. U. Daihani, "Komputerisasi Pengambilan Keputusan." PT Elex Media Komputindo, Jakarta, 2001.

[6] H. Mujiati, "Analisis Dan Perancangan Sistem Informasi Stok Obat Pada Apotek Arjowinangun," Speed J. - Sentra Penelit. Eng. dan Edukasi, vol. 11, no. 2, pp. 24 28, 2014.

[7] E. Maiyana, "Perancangan Aplikasi Media Informasi Lowongan Kerja Perusahaan Bagi Pencari Kerja Berbasis Web," J. Sains dan Inform., vol. 3, no. 2, p. 118, 2017, doi: 10.22216/jsi.v3i2.2893.

[8] L. Magdalena and A. Rachman, "Aplikasi Pendaftaran Siswa Baru Dengan Sistem Seleksi Menggunakan Metode Simple Additive Weighting (SAW) Pada SMK Miftahul Huda Ciwaringin,” J. Digit, vol. 7, no. 1, pp. 38-49, 2017.

[9] R. Nasrullah, "Riset Khalayak Digital: Perspektif Khalayak Media Dan Realitas Virtual Di Media Sosial," J. Sosioteknologi, vol. 17, no. 2, pp. 271-287, 2018, doi: 10.5614/sostek.itbj.2018.17.2.9.

[10] A. Kadir, "Dasar Pemrograman Web Dinamis Menggunakan PHP." C.V ANDI OFFSET, Yogyakarta, 2008.

[11] B. Hariyanto, "Dasar Informatika \& Ilmu Komputer Disertai Aksi-aksi Praktis." Graha Ilmu, Yogyakarta, 2008.

[12] S. Zakir and H. Wandi, "Aplikasi Sistem Pakar Penghitungan Zakat Maal Menggunakan PHP/MySQL," J. Pendidik. dan Inform. ISSN 2540-8666, vol. 1, no. 1, pp. 61-69, 2017, doi: http://doi.org/10.5281/zenodo.241513.

[13] R. A. Sukamto and M. Shalahuddin, "Rekayasa Perangkat Lunak Terstruktur dan Berorientasi Objek.” Informatika, Bandung, 2014.

[14] A.-B. Bin Ladjamudin, "Analisis dan Desain Sistem Informasi." Graha Ilmu, Yogyakarta, 2005.

[15] R. R. Fadila, W. Aprison, and H. A. Musril, "Perancangan Perizinan Santri Menggunakan Bahasa Pemograman PHP / MySQL Di SMP Nurul Ikhlas," CSRID $J$. , vol. 11, no. 2, pp. 84-95, 2019.

[16] H. A. Musril, Jasmienti, and M. Hurrahman, "Implementasi Teknologi Virtual Reality Pada Media Pembelajaran Perakitan Komputer," JANAPATI J. Nas. Pendidik. Tek. Inform., vol. 9, no. 1, pp. 83-95, 2020.

[17] P. Setiawan, Sulistiowati, and J. Lemantara, "Rancang Bangun Aplikasi Pengolahan Data Evaluasi Proses Belajar Mengajar Berbasis Web Pada STIKES Yayasan RS. Dr. Soetomo Surabaya," Jsika, vol. 4, no. 2, pp. 1-6, 2015.

[18] N. Afriani, S. Derta, and Charles, "Perancangan Sistem Informasi Pengelolaan Praktik Kerja Lapangan (PKL) di SMK Negeri 2 Bukittinggi," J. Sains, Inform. dan Ekon., vol. 2, no. 2, pp. 79-86, 2019.

[19] R. Sagita, F. Azra, and M. Azhar, "Pengembangan Modul Konsep Mol Berbasis Inkuiri Terstruktur Dengan Penekanan Pada Interkoneksi Tiga Level Representasi Kimia Untuk Kelas X SMA,” J. Eksakta Pendidik., vol. 1, no. 2, pp. 25-32, 2017, doi: $10.24036 /$ jep.v1i2.48.

[20] R. R. Hake, “Analyzing Change/Gain Scores,” Am. Educ. Res. Assoc. Div. D, pp. 14, 1999. 